\title{
Investigation of the Repairing and Strengthening Methods in Historical Structures
}

\author{
Filiz Karakus \\ General Directorate of Foundations, Ankara, Turkey, \\ E-mail: ferdemir06@gmail.com
}

\begin{abstract}
This study is focused on repairing and strengthening methods to protect and transfer from the the historical structures, which are the most important parts of our irreplaceable cultural heritage and which enable us to acquire the sense of national identity, to the future. Keeping cultural values that make up historical environment and give life to cities and transferring them to future generatios with their orginal qualities is one of the most important problems in the field of conservation. In this article, firstly the source research has been carried out in order to determine the repairing and strengthening techniques that can be applied in historical buildings, then examples of the application have been examined. The article aims to reveal all the restoration and strengthening methods that can be applied for the protection of historical masonry structures and the situations in which these methods are applied.
\end{abstract}

Key Words: Historical buildings, conservation, structural problems, repairing, strengthening.

DOI: $10.7176 / J S T R / 5-5-10$

\section{Tarihi Yapılarda Onarım ve Güçlendirme Yöntemlerinin Incelenmesi}

Özet

$\mathrm{Bu}$ çalışmada milli kimlik duygusu edinmemizi sağlayan ve kültürel mirasımızın yeri doldurulamayan en önemli parçaları olan tarihi yapıların günümüzden geleceğe aktarılmasını ve korunmasını sağlayacak onarım ve güçlendirme yöntemleri üzerinde durulmaktadır. Tarihi çevreyi oluşturan, şehirlere hayat veren kültür değerlerini yaşatmak ve bunları özgün nitelikleriyle gelecek nesillere aktarmak korumacılık alanındaki en önemli sorunlardan biridir. Makalede, tarihi yapılarda uygulanabilecek onarım ve güçlendirme tekniklerinin tespiti için öncelikle kaynak araştırması yapılmış, konuya ilişkin uygulama örnekleri incelenmiştir. Makale, tarihi yığma yapıların korunması için uygulanabilecek tüm onarım ve güçlendirme yöntemlerini ve bu yöntemlerin hangi durumlarda uygulandığını ortaya koymayı hedeflemektedir.

Anahtar Kelimeler: Tarihi yapılar, koruma, yapısal sorunlar, onarım, güçlendirme.

1. Giriş

Ülkemizdeki ve dünyadaki tarihi yapılar gerektiği gibi korunamamaktadır. Depremler, doğal afetler, olumsuz çevre koşulları ve fiziksel-kimyasal bozulmalar ve insanoğlundan kaynaklı nedenler bu yapıların bozulma sürecini hızlandırmaktadır.

Ülkemizde tarihi yapıların büyük bir çoğunluğu yapısal olarak iyi durumda değildir, bu yapılar ihmal, yanlış strateji, kasıt ve bilgisizlikle tahrip edilmiş ve kullanılamayacak duruma gelmiştir. Sözü edilen nedenlerden dolayı taşıyıcı sistemlerinde ciddi sıkıntılar ortaya çıkmıştır. Pek çok medeniyetten izler taşıyan ülkemizde, geçmişle aramızda bir bağ oluşturan kültürel ve mimari mirasın korunması ve onarımı çok önemlidir.

$\mathrm{Bu}$ çalışmanın amacı, yapısal sistemi zarar görmüş tarihi yapıların korunması ve gelecek nesillere aktarılabilmesi için uygulanacak olan onarım ve güçlendirme yöntemlerinin tespiti ve bu yöntemlerin hangi durumlarda uygulandığının ortaya konulması ile bu konuda çalışan uzmanlara yardımcı

81 | P a g e

www.iiste.org 
olunmasıdır. Bunun için öncelikle ülkemizde ve diğer ülkelerde uygulanan güçlendirme yöntemleri kaynak araştırmaları yapılarak incelenmiş ve gruplandırılmıştır. Söz konusu yöntemlerin ne amaçla kullanıldığı, uygulamanın nasıl yapıldığı anlatıldıktan sonra bu yöntemlerin uygulandığı birer örnek verilmiş̧ir. Ancak; verilen uygulama örnekleri henüz aradan yeterli süre geçmemesi nedeniyle neticelenmeyen durumlar oldukları için uygulama sonuçları hakkında net bir bilgi verilememesi bu çalışmanın sınırlılıklarını oluşturmaktadır. Tarihi yığma yapılara müdahale sırasında ve öncesinde dikkat edilmesi gereken hususlar da makalenin sonuç bölümünde ele alınmıştır. Tarihi yapılar, geçmişteki sosyolojik, ekonomik, politik ve dinsel yaşam hakkında pek çok bilgi aktarmaktadırlar. Bu yapıların onarım ve güçlendirmesine ait toplu bir başvuru kaynağı olabilecek nitelikte olması nedeniyle çalışmanın bulguları önemlidir.

\section{Tarihi Yığma Yapılarda Onarım ve Güçlendirme Teknikleri}

Günümüzde anıtların korunmasındaki temel yaklaşım sürekli bakımlarının sağlanması olmasına rağmen birdenbire ortaya çkan yangın, deprem, toprak kayması gibi felaketler ise büyük ölçekli müdahaleler yapılmasını gerektirebilir. Bu müdahaleler yapılırken kullanılan yöntemleri tarihi yapının yapıldı̆̆ 1 malzeme ile taşıyıcı sistemin sağlamlaştırılması ve temelin sağlamlaştırılması olarak iki ana başlık altında toplamak mümkündür.

Bu çalışma kapsamında; tarihi yapıların onarım ve güçlendirilmesinde kullanılan tüm yöntemler ortaya konulmaya çalışılmıştır. Fakat şunu unutmamak gerekiyor ki bu yöntemlerin bir kısmında kullanımı anlatılan çimento harçlı imalatlar tarafımızdan kabul görmemesine rağmen bazı durumlarda başka çözüm önerileri henüz geliştirilemediği için bu yöntemlerin ve malzemelerin kullanılması kaçınılmaz olmaktadır. Buna rağmen, bu yöntemlerin uygulamasında yapıyı çimentonun olumsuz etkilerinden korumak için gerekli önlemlerin alınması gerekmekte olup eski eser yapıların restorasyonunda çalışan uzmanların bu konuyu göz ardı etmemesi gerekmektedir.

\subsection{Tarihi Yapının Yapıldığı Malzemenin ve Taşıyıcı Sistemin Sağlamlaştırılması}

Tarihi yapılar; taşıyıcı sistemi oluşturan kubbelerin, tonozların, kemerlerin, sütunların ve duvarların yoğun ve sürekli etkileşimi nedeniyle çok karmaşık bir yük taşıma davranışına sahiptir [1]. Bu yapılarda ahşap, taş, tuğla, kerpiç, bağlayıcı olarak harç gibi malzemelerin yaygın olarak kullanıldığını görmekteyiz.

Sözü edilen taşıyıcı sistem elemanlarının ve kullanılan malzemelerin sağlamlaştırılmasında uygulanan yöntemler değiştirme-yenileme ve tamamlama, takviye-güçlendirme ile deformasyon ve sorun kaynağına çözüm geliştirme olarak üç grup altında toplanabilir.

2.1.1. Değiştirme-yenileme ve tamamlama: Tarihi yapının yapıldığ malzemenin ve taşıyıcı sistemin sağlamlaştırılması konusunda en basit uygulamalar olan kısmi değiş̧tirme ve tamamlama ile tekrar derzleme ve donatılı derzleme uygulamaları bu başlık altında ele alınacaktır.

a) Kısmi değiştirme ve tamamlama (Local substitution): Derin çatlak ve ezilme gibi hasar durumlarında, bozulma ve parça kayıplarında, en etkili çare bozulmuş malzemelerin kademeli olarak kaldırılması ve aynı veya daha geniş alanda tekrar inşa edilmesidir. Bu yöntem, binanın tarihi değerine göre değerlendirilmelidir, böylece her bir aşamada kargir yapının belli bir bölümü bozulmamış kalır [2].

Değiştirme işlemi malzemenin değiştirilmesi dışında elemanın değiştirilmesi ve taşıyıcı sistemin değiştirilmesi şekillerinde de uygulama alanı bulabilmektedir. Malzemenin kısmi değiştirilmesinde, hasar gören ve bozulan malzeme yeni malzemeyle değiştirilir [3].
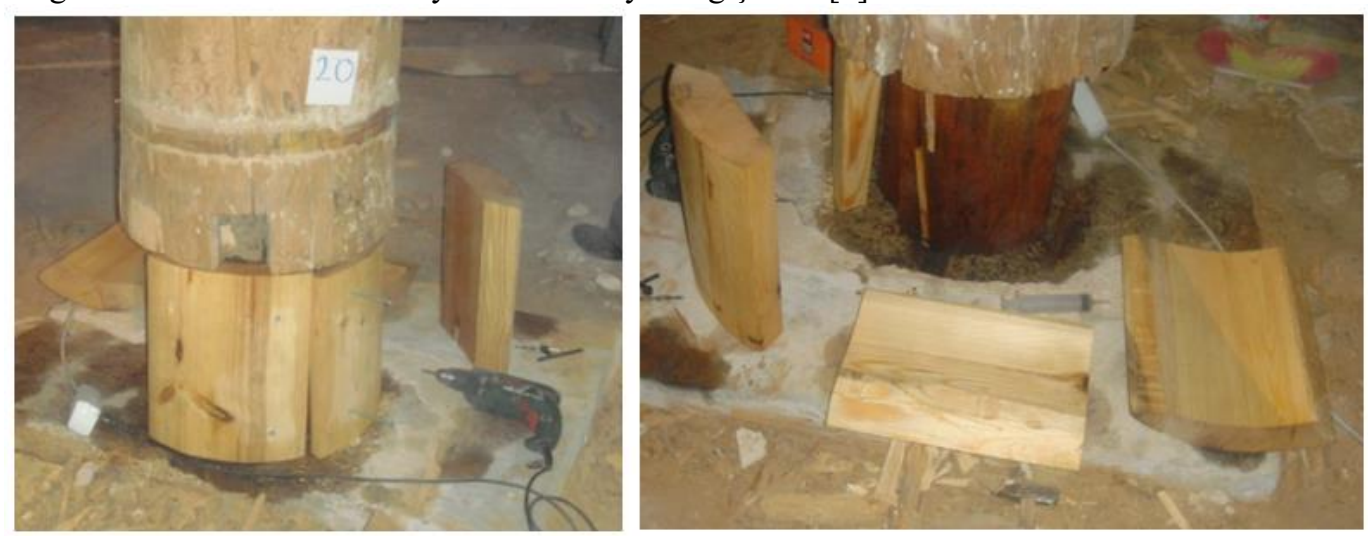

Şekil 1. Ankara Arslanhane Camii ahşap sütunlarda kısmi tamamlama, 2011 [4]

82 | P a g e

www.iiste.org 
b) Tekrar derzleme/Donatılı derzleme (Repointing/Reinforced repointing): Tekrar derzleme, bozulmuş harçların daha uyumlu ve mekanik özellikleri daha iyi bir harçla değiştirilmesidir. Böylece derzlerdeki gerilme ve sıkıştırma mukavemeti artar. Ayrıca, taşlarda bozulmaya neden olan problemlere yol açan suyun derzlerin arasından nüfuz etmesini engeller. Eğer kullanılan harç orijinal olanıyla benzer özelliklerde değilse uygulama taşın bozulmasını hızlandırır [5].

Derzleme işlemleri boşlukları, bozulmuş derzleri ve küçük oyukları doldurmak için kullanılır. Estetik olarak hoş bir sonuç almak için büyük dikkat gösterilmelidir. Ayrıca kullanılan harç, su yalıtımı sağlamalı, gerilmelere, güneş 1şığı ve sıcaklık hareketlerine karşı koymak için yeterli mukavemeti sağlamalıdır [2].

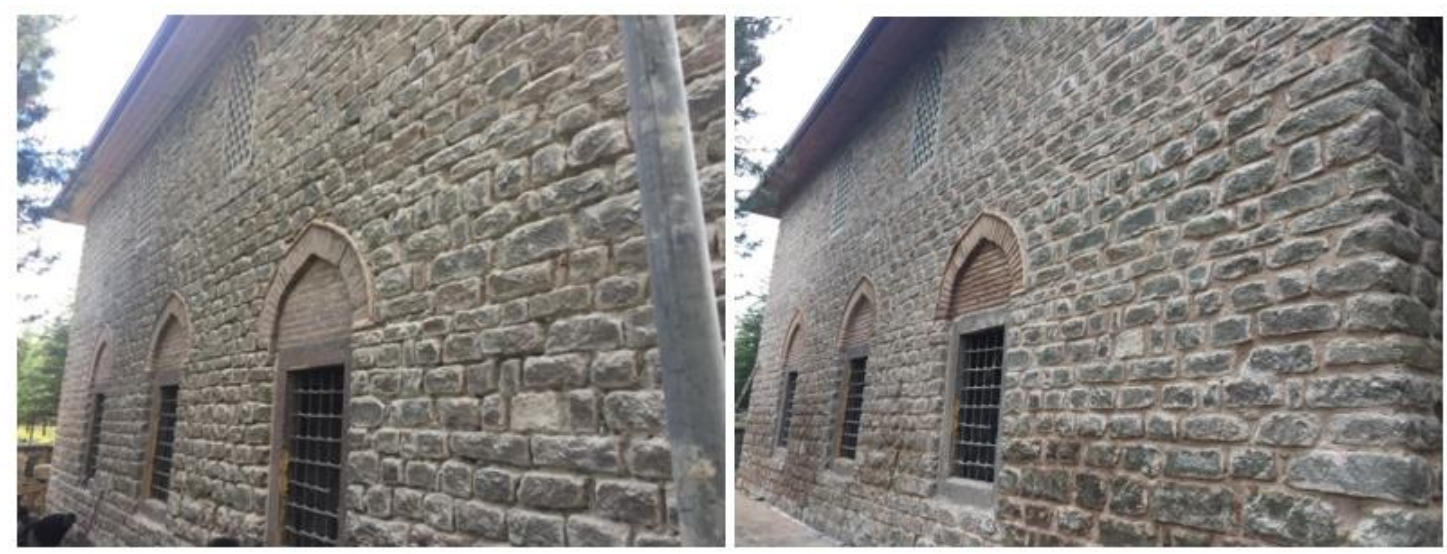

Şekil 2. Ankara Kahramankazan Saray Camii derz açma ve derz işlemi yapılırken, [4]

2.1.2. Takviye-güçlendirme: Tarihi yapının taşıyıcı sisteminin sağlamlaştırılmasında daha ciddi müdahaleleri içeren takviye-güçlendirme başlığı altında ise enjeksiyon, dikiş, destekleme-payandalama, kuşaklama ve sargı uygulamaları, ön germe ile güçlendirme, sabitleme-ankraj, hatıl oluşturulması, taş ekleme, beton kolon oluşturma ve betonarme katman oluşturulması yöntemleri incelenecektir.

a) Enjeksiyon (Injection): Taş ögelerde meydana gelen çatlaklar 0-2 mm den küçük ise onarıma ihtiyacı yoktur. Eğer çatlak $0.3 \mathrm{~mm}$ den büyük $3 \mathrm{~mm}$ den küçük ise onarım için enjeksiyon harcı kullanılabilir [6]. Enjeksiyon kargir duvarların zayıf ve gözenekli harçlarının dayanıklılık ve homojenliğini iyileştirmek için de kullanılmaktadır.

Edirnekapı Mihrimah Sultan Camiinde kılcal genişliği 8 mm'den az olan çatlaklar, duvarın özgün harcının kalitesine uyan bir enjeksiyon harcı ile 1 3 bar gibi düşük basınç altında enjeksiyon yöntemi ile dolduruldu [7].

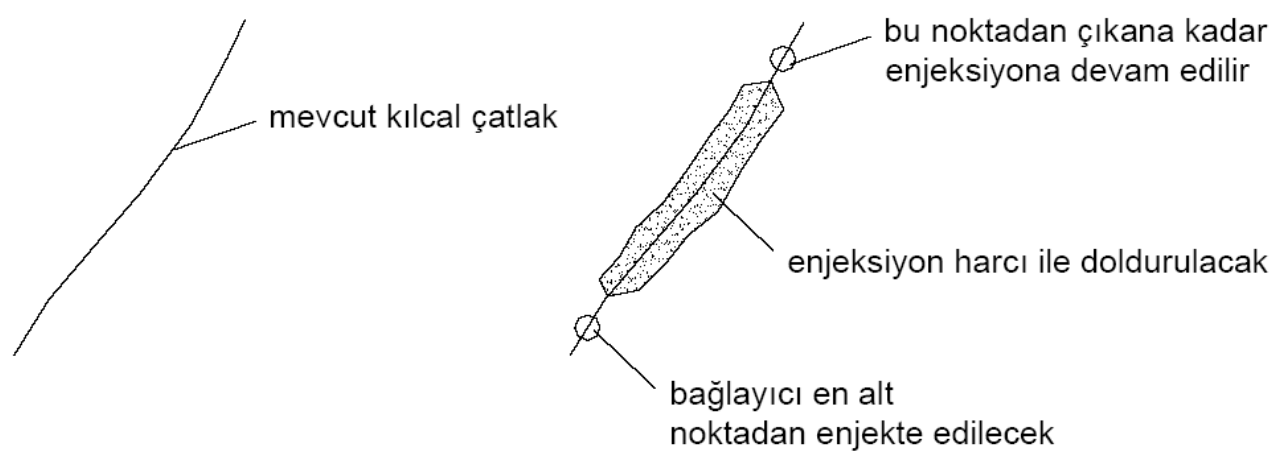

Şekil 3. Kılcal çatlak onarımı [7] 


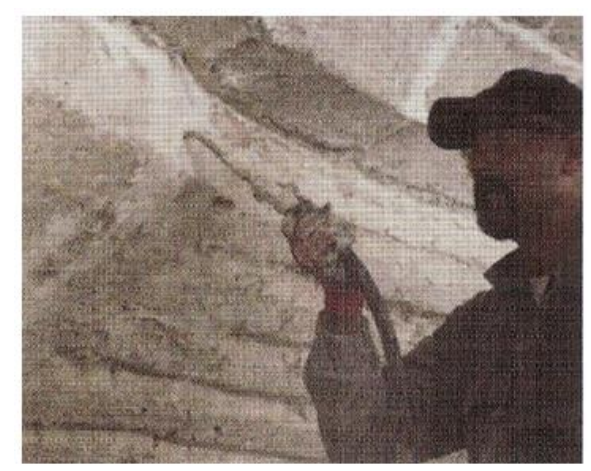

Şekil 4. İstanbul, Edirnekapı Mihrimah Sultan Camii enjeksiyon işlemi, 2009 [8]

b) Dikiș (Stitching): Yapıda oluşan çatlaklar $10 \mathrm{~mm}$ den büyükse veya duvarı oluşturan taşlar düşmüşse, enjeksiyon işleminden daha geniş bir uygulama yapılması gerekir. Dikiş yönteminde demir ve paslanmaz çelik elemanlar kullanılarak duvarın iki yüzeyi birleştirilerek kapatılır. Düşey çatlaklarda çatlağa bitişik taş ya da tuğlalar çıkarılır ve dikiş elamanları ya da çelik barlar eklenir, duvarın boşlukları, orjinaline uygun harç ile doldurulur. Bu işlemin duvarın diğer yüzünde de uygulanması gerekir [9].
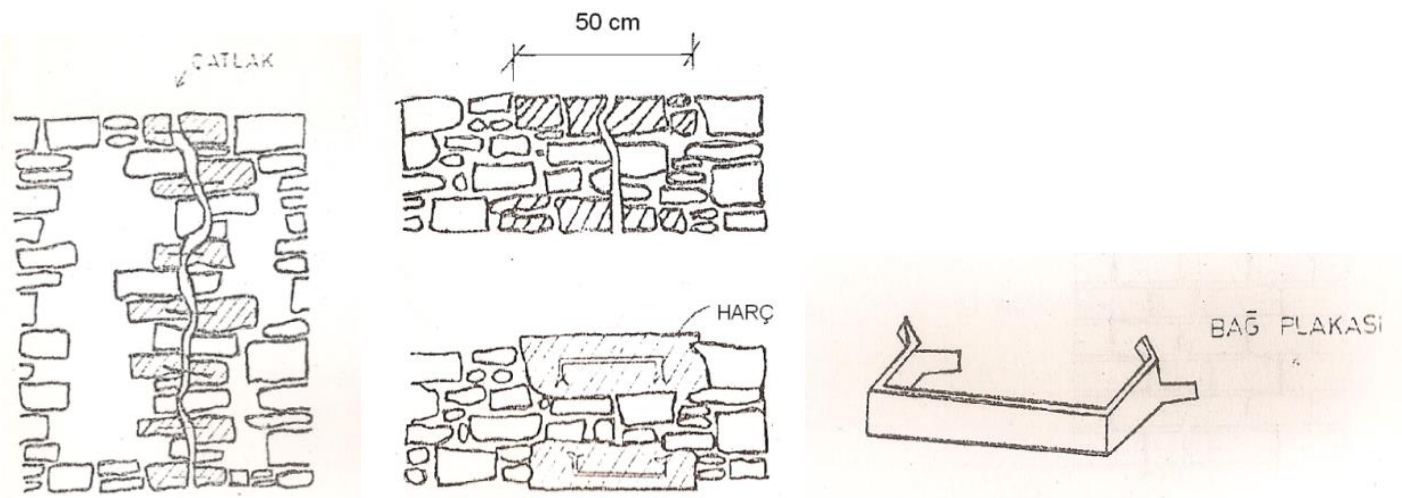

Şekil 5. Taş duvarlarda düşey çatlakların dikiş yöntemi ile onarımı [9]

Edirnekapı Mihrimah Sultan Camiinde çatlaklar orta genişlikte ve genişliği $8 \mathrm{~mm} 24 \mathrm{~mm}$ ise, paslanmaz çelik çubuklarla dikildikten sonra yine duvarın özgün harcının kalitesi ile benzer özellikler taşıyan bir enjeksiyon malzemesi ile 1 3 bar gibi düşük basınç altında enjeksiyon yöntemi ile doldurularak onarıldı [7].
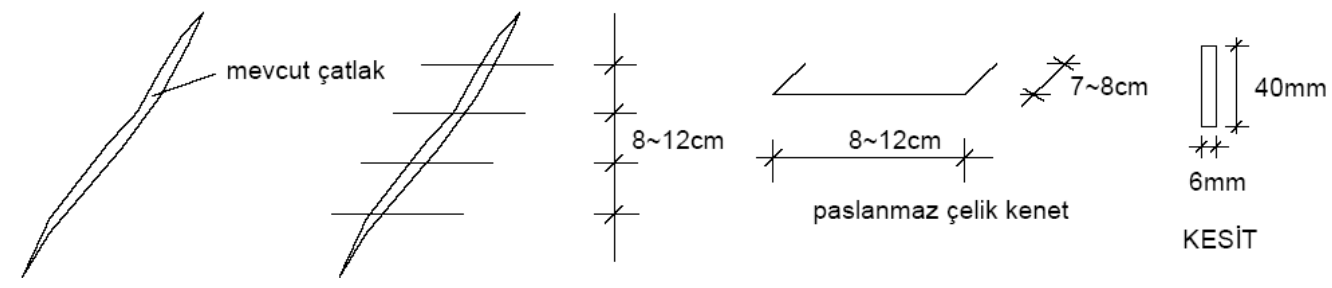

Şekil 6. Orta genişlikteki çatlakların onarımı [7] 

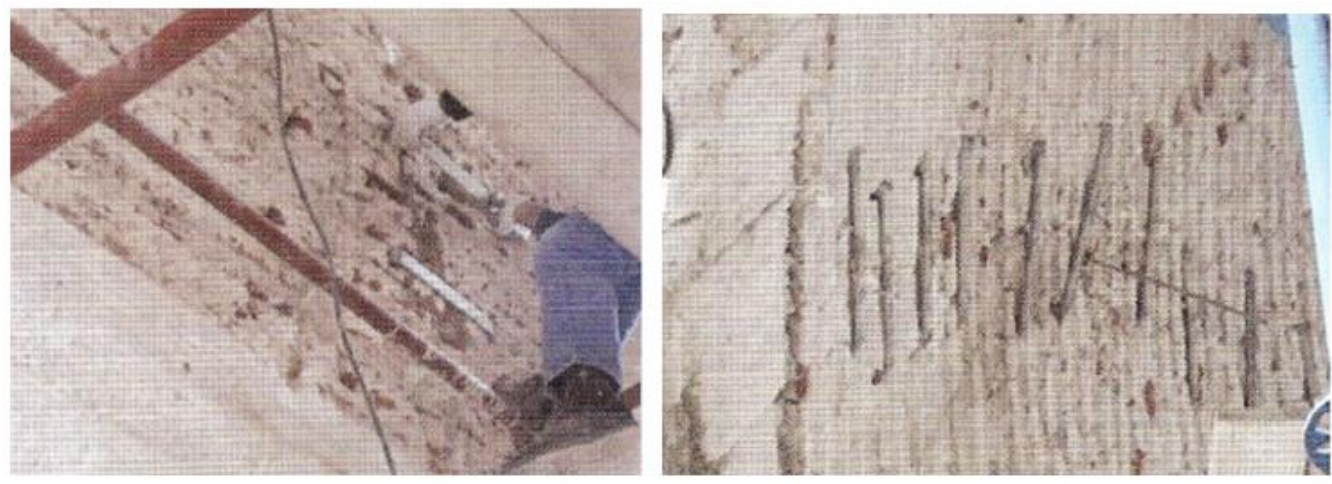

Şekil 7. İstanbul, Edirnekapı Mihrimah Sultan Camii dikiş işlemi, 2009 [8]

c) Destekleme-payandalama (Buttressing-Strutting): Kemer, tonoz, kubbe gibi taşıyıcılar zemindeki aksaklıklar, deprem gibi etkiler sonucunda eksenlerinden ayrılırlar, bunun neticesinde çatlaklar oluşur. Bu sorunu çözmek için köşelere, kemer mesnet hizalarına masif, ya da uçan payandalar ilave edilir [6]. Osmanlı Dönemi onarımlarında masif payandalar çoğunlukta olmasına rağmen özellikle son dönemlerde görsel nedenlerle, ağır kütleli masif payandalar yerine uçan payandalar ya da geçici payandalar uygulanmaktadır [10].

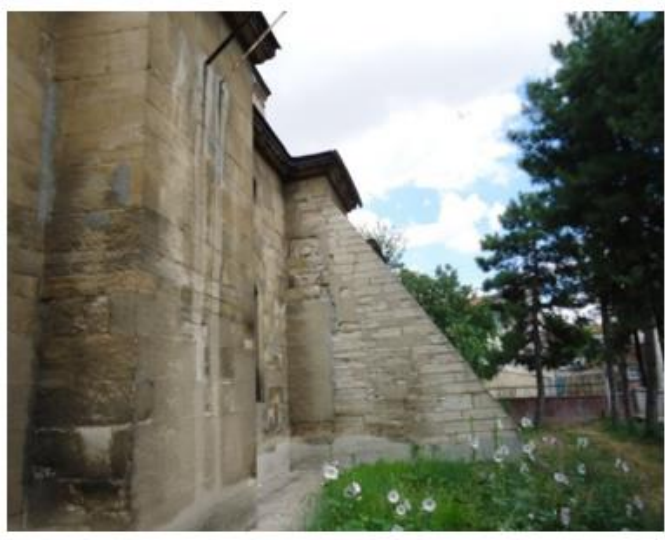

Şekil 8a.Çankırı Ulu Camii masif payandalar,

2011[11]

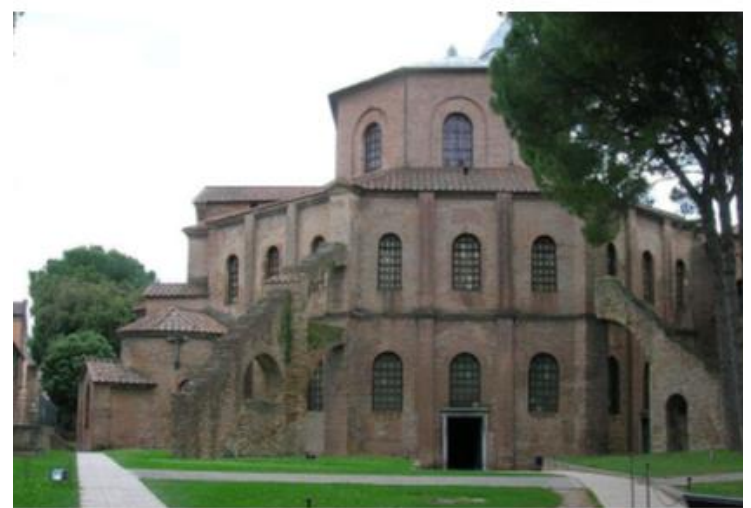

Şekil 8b. San Vitale Kilisesi uçan payandalar

[12]

d) Kuşaklama ve sargı uygulamaları: $\mathrm{Bu}$ başlık altında bağlantı çubukları-gergi uygulaması, çemberleme-sıkıştırma, dıştan lifli polimerler ile güçlendirme, kesit genişletme-mantolama ve çelik levhalarla kuşaklama uygulamaları ele alınmıştır.

- Bağlantı çubukları-gergi uygulaması (Tie-bars): Gergiler, taşı1ıı sisteme ankre edilen kemer ve tonozlardaki yanal itme kuvvetlerini hafifletmeye katkıda bulunan çelik elemanlardır [3]. Bu yöntemin yap1 duvarlarında uygulanması halinde, gergi demirlerinin uçlarındaki bulonlar mümkün olduğu kadar sıkılarak donatıya bir gerilme verilmekte, bir bakıma ön gerilme sağlanmaktadır. Bu demirler sayesinde duvarın direnci arttırılır ve dağılmasının önüne geçilir. Gergi demirlerinin konulacağı en uygun yer duvar yüksekliğinin 1/3 aralıklarla bölünerek bulunan yüksekliklerdir [13].

Edirnekapı Mihrimah Sultan Camiinde yapının düşey ve yatay yükler altındaki davranışını iyileştirmek amacıyla ana kubbeyi mihrap cephesi etrafında taşıyan kemerde üzengi çizgisine yakın bir kotta gergi düzenlemesi yapılmıştır. 


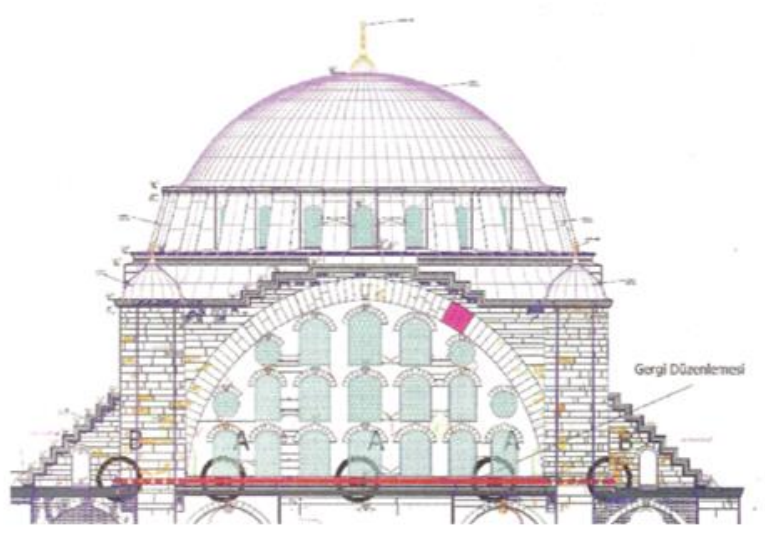

Şekil 9. Mihrimah Sultan Camii mihrap cephesi gergi düzenlemesi görünüş [14]

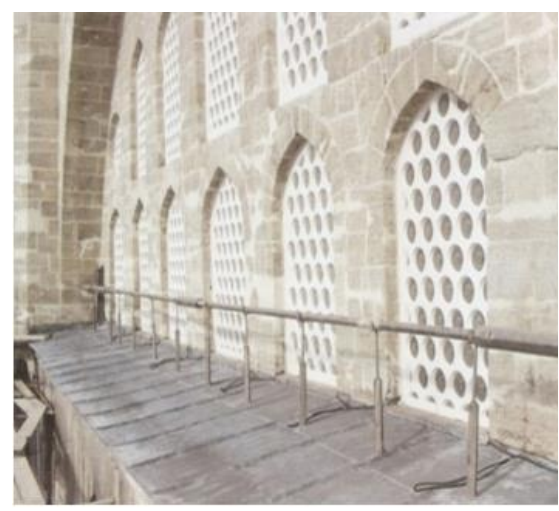

Şekil 10. Mihrimah Sultan Camii gergi düzenlemesi, 2009 [8]

- Çemberleme- Sikıştırma (Confinement): Dağılma tehlikesi gösteren düşey taşıyıcı elemanlar metal çemberlerle sarıp sıkıştırılır. Son cemaat yerlerinde ya da iç mekânlardaki çatlayan sütunlar bu metotla sarılarak sağlamlaştırılır [6]. Metal halkalarla çemberleme, çok fazla basınç yüzünden kolon ve ayaklarda çatlama, ezilme, parçalanma görüldüğü yerlerde uygulanabilir [3].

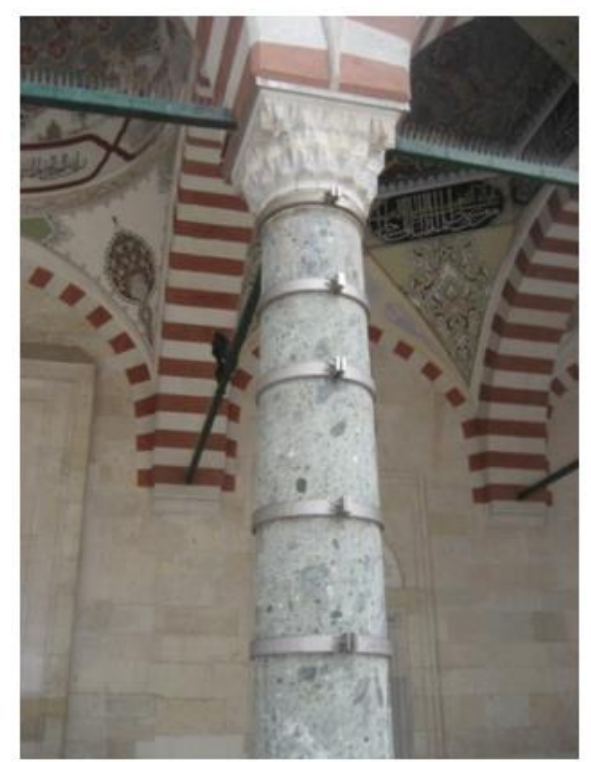

Şekil 11. Edirne Üç Şerefeli Camii sütunları çemberleme uygulaması, 2011 [15] 
- Diştan Lifli Polimerler ile Güçlendirme (External Reinforcement): Yı̆̆ma duvarlarda yapılabilecek diğer bir uygulama ise lifli polimer ile güçlendirmedir. Yığma yapıların duvarlarının kesmeye ve eğilmeye karşı mukavemeti lif takviyeli polimer sistemlerle arttırılabilir. Duvarlarda eğilmeye karşı boyuna, kesmeye karşı enine doğrultuda lifli polimer uygulanabilir [6]. Cam, karbon ve aramid lifler güçlendirmede kullanılan lifler arasında en yaygın olanlarıdır [5]. Makedonya Üsküp Mustafa Paşa Camiinde, 1963 Üsküp depremi merkez kubbe, son cemaat kubbeleri, doğu cephe ve minare ile cami taşıyıcı sistemine yoğun olarak zarar vermiştir. 1968 yılında bu zararlar çimento harç esaslı karışımların enjeksiyonu ile onarılmıştır. 2007 yılında başlayan onarım çalışmalarında, kubbe üzerinde 1968 'de yapılan çimento harç tabakası kaldırıldıktan sonra kubbe taşıyıcı sistemine yönelik müdahalelere geçilmiştir. İlk olarak ana kubbenin tabanında önceden yapılan betonarme halka kireç esaslı bir karışımla kaplandı. Sonraki aşamada kubbede horasan sıva yapılıp kubbe tabanının çevresi boyunca epoksi yapıştırıcı ile 2,9 m genişliğinde 7 sıra minimum $330 \mathrm{gr} / \mathrm{m}^{2}$ ağırlı̆̆ında tek yönlü karbon lifli elyaf (CFRP) bantları sarılmış, üzerine sıva tutması için silis kumu ile kumlama yapılmış ve daha sonra çamur harçlı sıva yapılıp kurşun kaplama yapılmıştır.
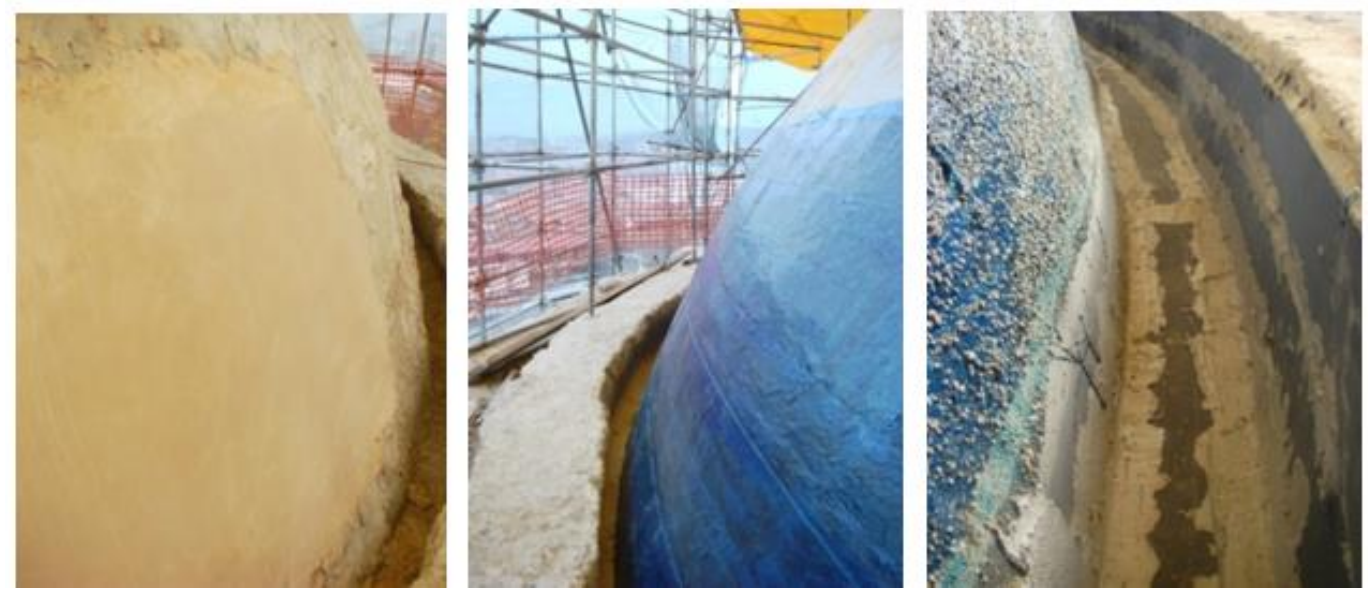

Şekil 12. Mustafa Paşa Camii kubbede karbon lif uygulaması, 2007 [16]

- $\quad$ Kesit genişletme, mantolama (Enlargement): Kesit genişletme yönteminde yeni bir malzeme bir taşıyıcı elemana veya kesite o eleman üzerindeki yükün daha geniş alanlara dağıtılması veya mukavemetinin arttırılması için eklenir. Bu yöntem herhangi bir taşıyıcı sistem elemanına uygulanabilir [3].

İstanbul Kabataş Erkek Lisesi'nde açılan muayene çukurları ile yapı temellerinde kullanılan ahşap kazıkların, yer altı suyunun etkisiyle çürümüş olduğu ve temellerin binanın boyutları ile orantılı olmadığ tespit edilmiştir. Duvarlarda ise deprem çatlaklarının oluştuğu görülmüştür. Taşıyıcı duvarların güçlendirilmesi kapsamında, bütün katlarda taşıyıcı duvarlarda bir veya iki taraflı hasır çelik donatı, duvarlara epoksili ankrajlarla bağlanarak püskürtme betonlu takviye yapılmıştır. Hasır çelikler birbirlerine en az $20 \mathrm{~cm}$ bindirilerek yerleştirilmiştir [6].
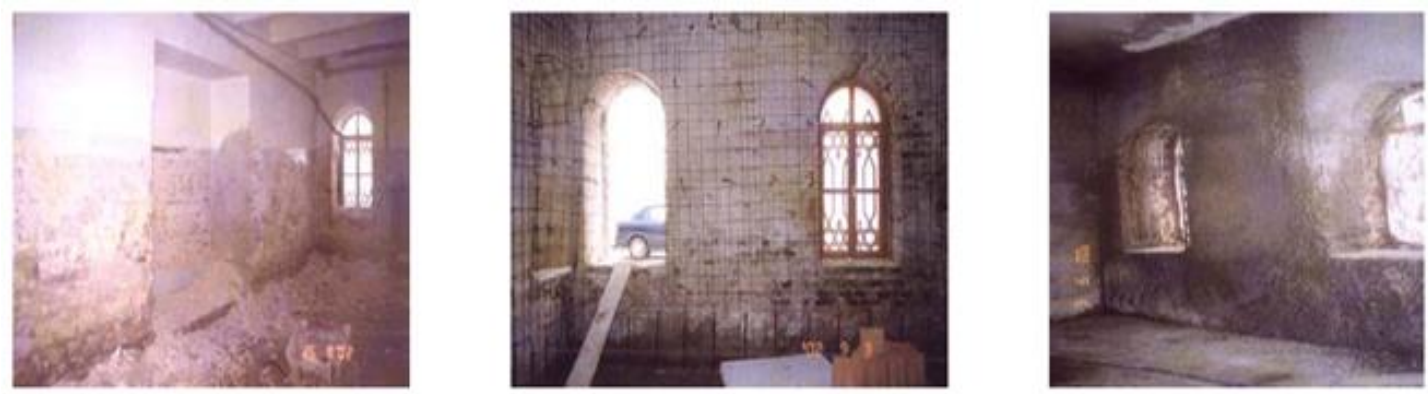

Şekil 13. İstanbul, Kabataş Erkek Lisesi duvarlara çelik hasır ve ankrajların yerleştirilmesi ve püskürtme betonunun tamamlanması [6] 


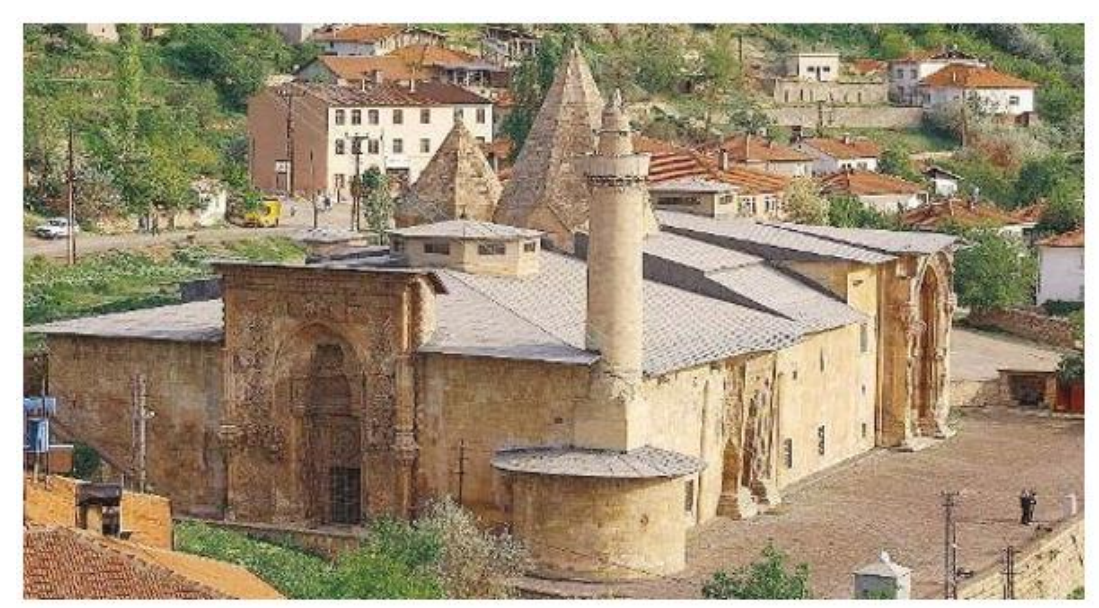

Şekil 14. Sivas Divriği Ulu Camii minare kaidesinde genişletme [17]

Sivas Divriği Ulu caminin minaresinde düşeyden başlayan ayrılmalara çözüm olarak kesit genişletilmiştir. Kaide çevresinde yapılan ek bir kütle ile taban alanı genişletilmiş; düşeyden ayrılan minarenin yıkılması önlenmiştir.

- C C Celik levhalarla kuşaklama: Bu yöntemde, duvarlar çelik levhalarla kuşaklanarak veya duvarın çatıya veya döşeme diyaframlarına monte edilerek kullanılan çelik levhalarla güçlendirilir.
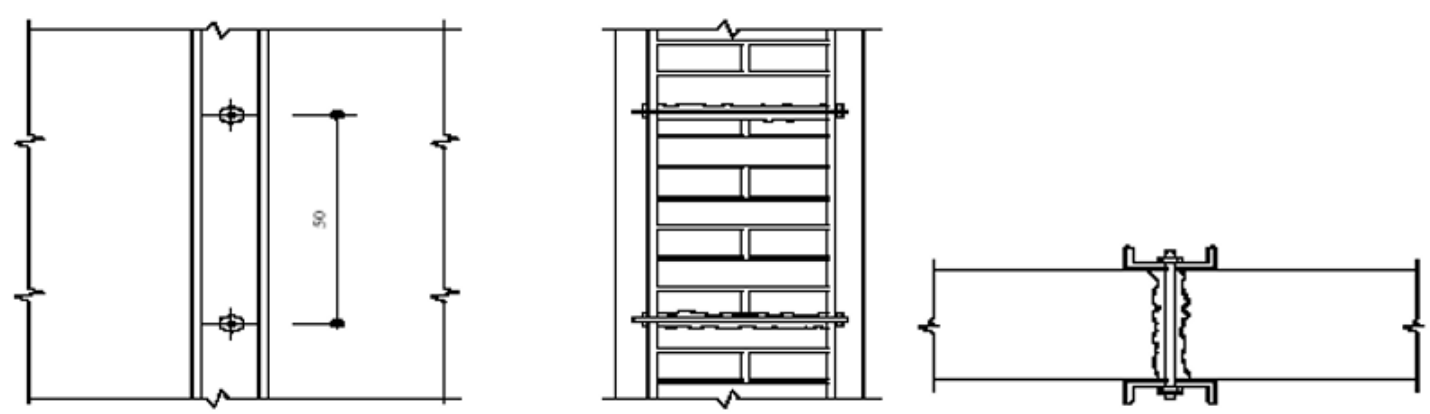

Şekil 15. Çelik levhalarla kuşaklama [6]

e) Ön germe ile güçlendirme (Prestressing): Kargir yapılar düşük gerilme ve kesme direncine sahiptir, gerilme kuvvetleri minimuma indirgenmiştir. Bazı durumlarda denge koşullarını sürdürebilmek için özellikle önceden oluşan hasar ve bozulmalar olduğunda veya beklenmeyen deprem ve toprak hareketleri meydana geldiğinde belli bir gerilme mukavemeti gerekir. Söz konusu gerilme mukavemeti, harici bağlantılar ile elde edilebilir. En çok kullanılan germe elemanları çelik donatılı çubuklar olup bunların korozyona karşı korumalarına dikkat edilmelidir. Özel paslanmaz çelikler, reçine çubuklar, karbon elyaf lifler, polimerik lifler veya diğer sentetik ipler çeliğe alternatif oluşturan malzemelerdir [2].

Edirnekapı Mihrimah Camii ana kubbede saptanan çatlakların oluşum nedenlerini belirlemek amacıyla üç boyutlu olarak ANSYS yazılımı yardımıyla modellenmiştir. Yapısal çözümlemeler, kubbenin özgün durumu ve diştan çekme çemberli durumu için yapılmıştır. Kubbe ile ilgili hesaplar sonucunda elde edilen verilerin değerlendirilmesi sonucunda kubbenin güvenlik düzeyinin arttırılması için kubbe eteğinde ( 24 m kotunda) yukarıdaki detaylara uygun olarak 1 adet çekme çemberi düzenlenmesine karar verilmiştir [7]. 

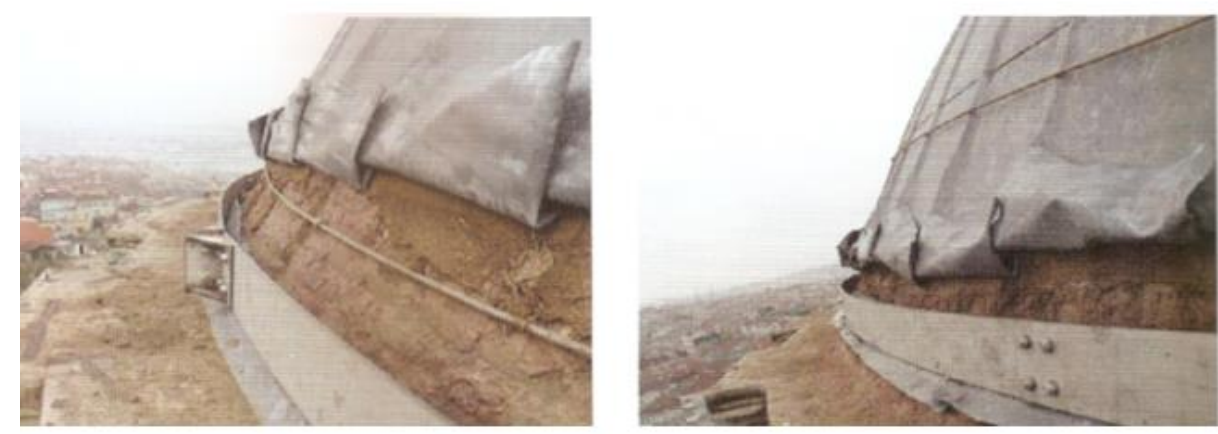

Şekil 16. Mihrimah Sultan Camii ana kubbe eteğinde uygulanan çekme çemberi [8]

f) Sabitleme- ankraj (anchoring): Ankraj, bir elemanın veya tüm strüktürün sabit bir strüktüre veya zemine sabitlenmesidir. Eleman bazında yapılan veya ankrajlama gerektiren dıştan güçlendirmelerde, elemanlar kesitin içine donatı çubuklarını sabitlemek için boşlukların arasından zorla girer. Diğer taraftan, strüktürü zemine sabitleyeceğin zaman orijinal dokuya zarar vermez ama görüntüyü değiştirir [2].

Farklı oturmaların ve özellikle eğilmenin oluştuğu yerlerde, bu değişiklikleri dengelemek ve hatta ters çevirmek yük dağı̆ımını değiştirerek mümkün olmaktadır. İtalya Piza Kulesinde, devrilme momentini azaltmak için kaynağa yakın kenarına ölü yükler yerleştirilmiş ve devrilme momenti \%20 seviyesinde azaltılmışıır [2].
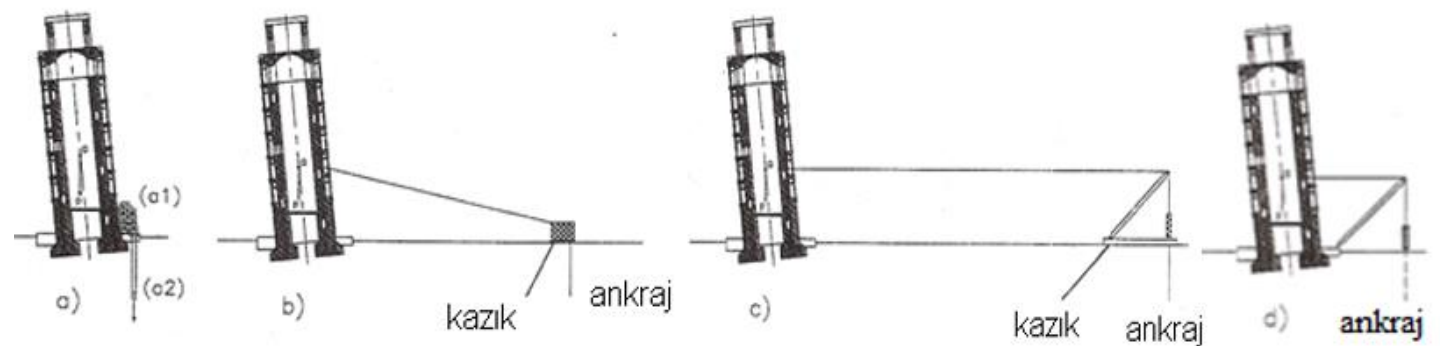

Şekil 17. Piza Kulesi ankraj1 [2]

g) Hatıl (çelik, sentetik çubuk veya betonarme vb.) olușturulması: Duvarların deformasyonu pencerelerin altında ve üstünde yoğunlaşan çatlaklarla ortaya çıkar; duvar davranışı döşeme seviyesindeki iyi yatay bağlantılar ile düzeltilebilir.

Bu bağlantı çelik veya sentetik çubuklardan yapılan hatıllar kullanılarak yapılabilir. Betonarme hatıllar da bu amaçla kullanılabilmesine rağmen tarihi binalarda kullanılması çok uygun değildir [2].

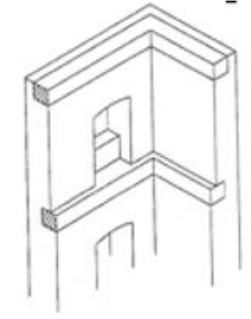

a) yatay bağlantı

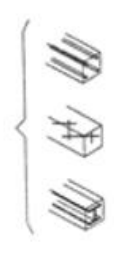

b) düşey bağlantı

Şekil 18. Deprem davranışının iyileştirilmesi için yatay ve düşey bağlantılar [2]

h) Tas ekleme: Duvar birleşimlerinde geniş düşey kırıklar veya ayrılmalar oluşabilir. Duvar bileşimlerini iyileştirmek için tuğla örmek veya kırık boyunca taş eklemek kullanılan bir yöntemdir (Şekil 19). 1 ve 2 
numaralı yerde gösterildiği gibi tuğla veya taş çıkarılır ve yeni malzeme 3 numarada gösterildiği gibi yerleştirilir. İki duvar arasındaki boşlukta uygun harçla doldurulur [6].

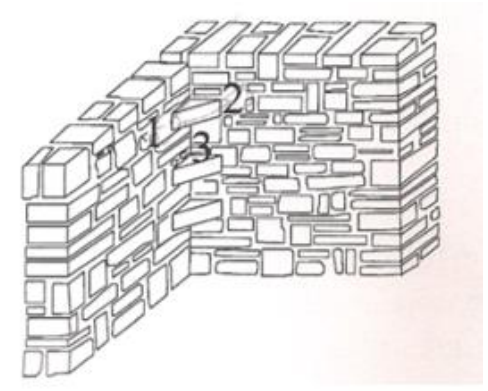

Şekil 19. Taş ekleme yöntemi [6]

i) Beton kolon oluşturma: Eğer köşe tamamen kopmuşsa, mevcut duvarı güçlendirmek için; çatı veya taşıyıcı sistem geçici desteğe alınmalı, sonra yığma duvardaki ek yerleri çıkarılıp temizlenmelidir. Betonarme donatısı hazırlanıp köşe duvarların içine bağlanmalıdır. Bu uygulama duvar bileşimini de güçlendirebilir [2].
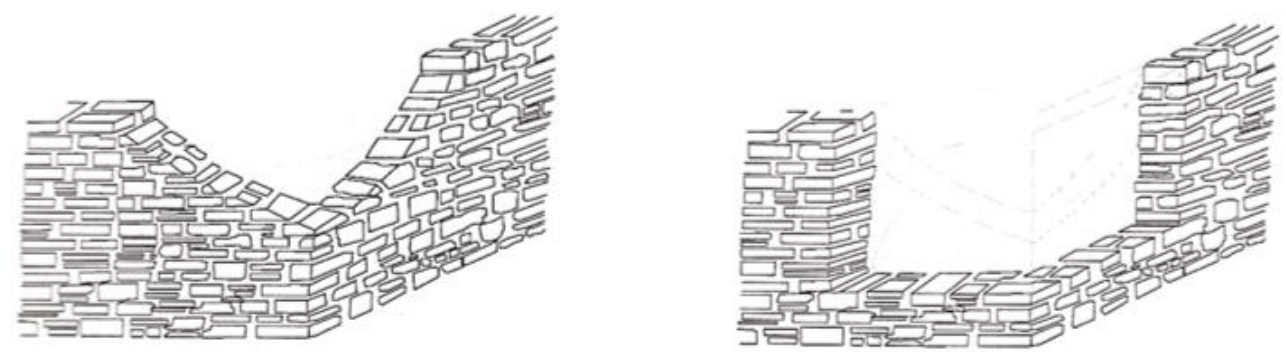

Şekil 20. Duvar köşelerinde oluşturulacak kolon için yapıllan hazırlık [9]

j) Betonarme katman: En uç yöntemlerden biri kemer ve ya tonoz sırtının ince bir betonarme katmanıly kaplanmasıdır. Döşemelerin kendi düzlemlerinde sabitliği için kullanılabilecek olan ince betonarme döşemeler tarihi binalarda son çare olarak düşünülmelidir.

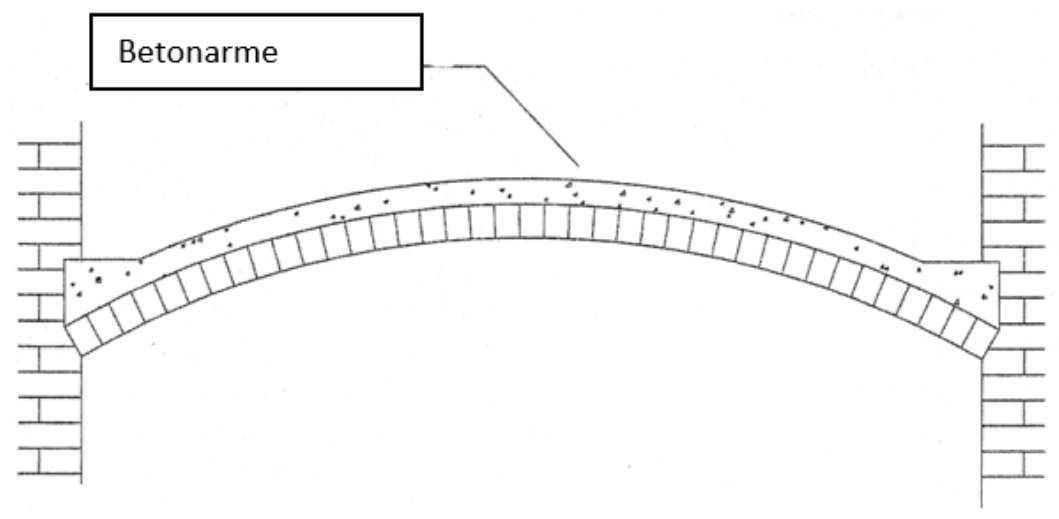

Şekil 21. Tonoz üzerinde ince betonarme katman [2]

2.1.3. Deformasyon ve sorun kaynağına çözüm geliştirme: Bu başlık altında dilatasyon derzi oluşturma, çelik kirişler ve yayların kullanılması, mekanik sistemler ile güçlendirme, sismik yalıtım ve su yalıtımı ele alınacaktır.

a) Dilatasyon derzi olușturma: Yapıda oturma probleminden kaynaklı çatlaklar olduğu zaman, özel testereler kullanılarak duvardaki ana çatlakları takip eden düşey derzler kesilerek dilatasyon derzi 
oluşturulmuş olur. Böylece, yapının belli bir miktar hareketine izin verilerek, binanın oturmalara daha fazla gerilme yaratılmadan uyum sağlayabilir hale getirilmesi sağlanabilmektedir.

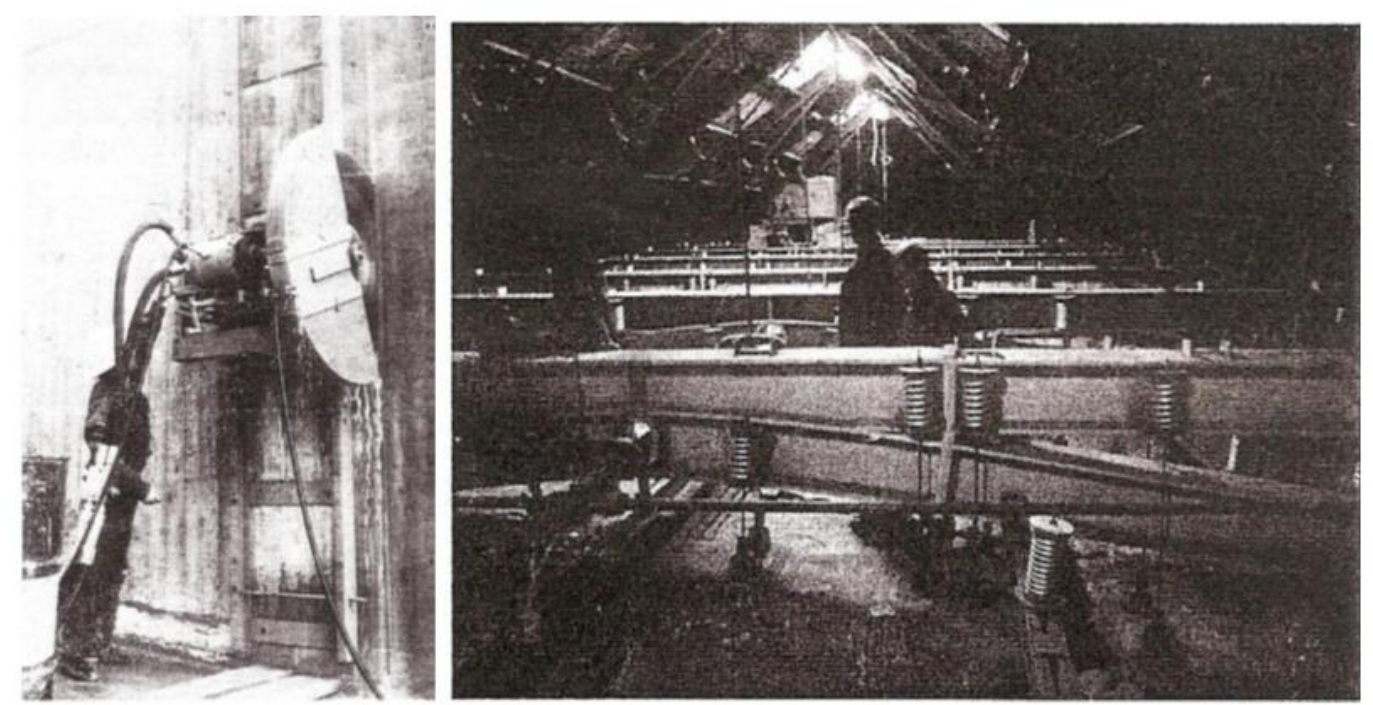

Şekil 22. Italya Modena Düklük Sarayında yapılan uygulama [2]

Şekil 23. Cenova Dükler Sarayı tonozu desteklemek için olan yayların ve çelik kirişler

b) Çelik kirișler ve yaylar kullanılarak: Geniş açıklıklı tonozların güçlendirilmesi, tonozun harici çelik kirişlerle asılması ile çözülebilir. Bu tür onarımlarda sıcaklık genleşmesinden doğan gerilmeler ve farklı malzemelerin değişen sıcaklık katsayılarından kaynaklanan taşıyıcı sistem büzülmelerinden kaynaklanan olası yan etkiler göz önünde bulundurulmalıdır [1].

c) Mekanik sistemler ile güçlendirme (kriko vb.): Taş yapılarda, merdivenler genelde büyük hasara ve hareketlere maruz kalır. Uygun çözüm; tablalı kriko gibi mekanik araçlarla uygun bir itme kurularak sağlanabilir, böylece merdiven taşları için gerekli olan basınç tekrar yaratılır. Daha sonra bloklar kriko kullanılarak önceki pozisyonlarına kaldırılır.

Bu tür bir çözüm İspanya'da Monforte Lemos Katedrali'nin tarihi merdivenlerinin dengesini tekrar kurmak için kullanılmıştır, dikey yer değiştirmeleri eski haline getirmek için dikey krikolar yatay olanlarıyla birlikte kullanılmıştır.

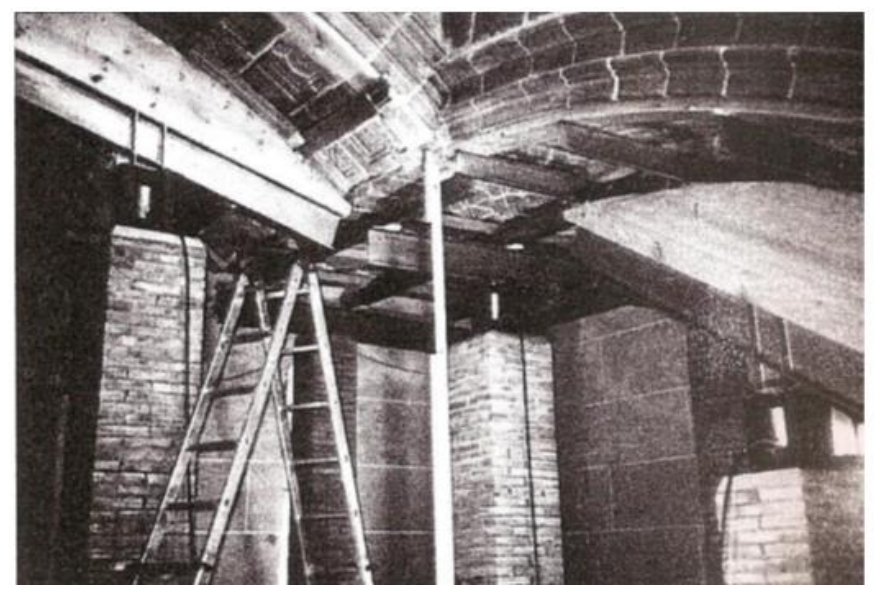

Şekil 24. Monforte Lemos Kardenal Kolejinin merdivenlerindeki deformasyonu düzeltmek için olan geçici strüktür ve krikolar [2] 
d) Sismik (Deprem) Yalıtım: Son dönemlerde, tarihi yapılarda ve bazı önemli çağdaş yapıların güçlendirilmesi amacıyla enerjiyi kendi içinde sönüme uğratarak kontrol etme eğilimi ağırlık kazanmaktadır [13].

Taban yalıtımının temel ilkesi; yapıların ve kuvvetli yer hareketlerinin özellikleri göz önüne alınarak; yapıların rijitliklerini azaltıp periyotlarını uzatmak, sönümlerini arttırarak yapılara daha küçük yatay yüklerin gelmesini sağlamak, yapıların orta şiddetli depremlerdeki hasarının önlenmesi ve çok şiddetli depremlerdeki hasarının daha küçük boyutlara indirilmesidir $[6,13]$.

e) Nemin uzaklaștırılması ( $\mathrm{Su}$ yalıtımı): Nemin yapıda kapiler olarak yükselmesi ve kristalize olması duvar genelinde ve yapı malzemelerinde bozulma ve çatlaklara yol açmaktadır. Bu durumu ortadan kaldırmak için muhtemel sebeplerin incelenmesi ve bu doğrultuda müdahale yönteminin belirlenmesi gerekir. Zemin suyu seviyesinin düşürülmesi, yağmur suyu toplama sisteminin düzenlenmesi ve drenaj yapılması yöntemleri, yapıdan suyun uzaklaştııılması için kullanılmaktadır.

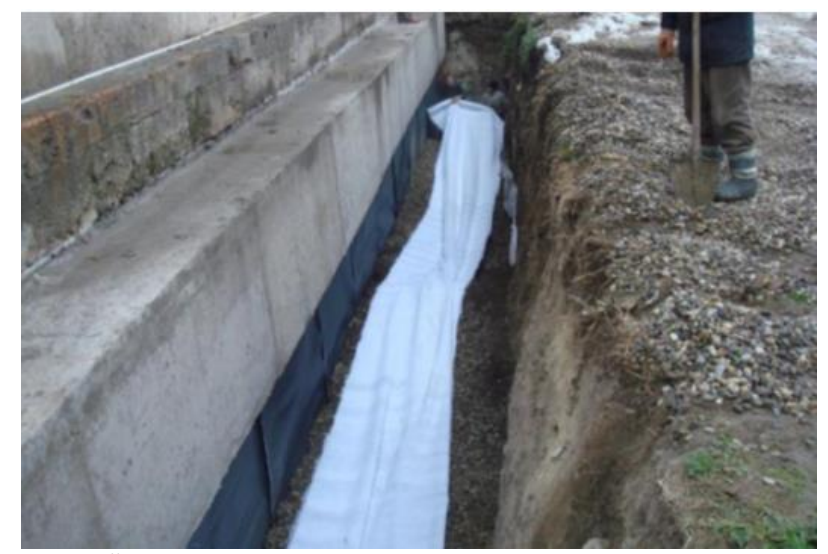

Şekil 25. Üsküp Mustafa Paşa Camii drenaj çalışması, 2007 [16]

\subsection{Temelin Sağlamlaştırılması}

Temel güçlendirmesi, bir binanın temel yüklerinin daha derin ve sağlam seviyelere dağıtılmasıdır. Bu yapılan işlemde, mevcut yüklerin tamamen veya kısmen zararsız bir şekilde taşınacağı yeni temeller yaratılır. Temel takviyesi hangi amaçla yapılırsa yapılsın, takviye yöntemine karar vermeden önce mutlaka sondajlar, deneme çukurları ve numuneler üzerinde laboratuar ortamında deneyler yapılıp incelenmelidir.

Eğer temelin oturmalara karşı takviyesi gerekiyorsa temel yükleri, oturmalardan etkilenmeyecek bir derinliğe aktarılmalıdır. Bunun için arazi profilinin ve zemin özelliklerinin bilinmesi gerekir. Öte yandan, temelin takviye edilmesini gerektiren neden doğru olarak belirlenmelidir [18].

Temelin sağlamlaştırılması için yapılan uygulamalar geleneksel yöntemler, zemin iyileştirilmesine dayanan yöntemler ve temel yüklerinin daha derindeki tabakalara aktarılması şeklinde üç başlık altında ele alınacaktır:

2.2.1. Geleneksel yöntemler: Çukur yöntemi olarak da bilinen bu yöntemle yığma yapılarda yapıdan gelen yüklerin daha geniş bir alana aktarılması sağlanır.

$\mathrm{Bu}$ yöntemde mevcut temele yeni ilaveler yapılarak yüklerin paylaşımı sağlanarak zemin gerilmeleri azaltılır. Temel altındaki zemin tamamen boşaltılarak temel alt kısmının derinleştirilmesi veya genişletilmesi ile oluşturulan boşluk hacminin sağlam ve stabil bir malzemeyle yeniden doldurulması sağlanır [13].

Edirnekapı Mihrimah Sultan Camiinde zeminde yapılan araştırma sondajlarında caminin temellerinin bölgedeki hâkim temel zemini olan yeşil killere oturduğu anlaşılmıştır. Üst kısımda bulunan moloz dolgudan sonra -4 veya -6 metreden sonra yeşil kil tabaka başlamaktadır. Kil-marn ardalanmasını takiben bir nevi geçiş oluşturan kum-çakıl örtüsü yer almakta, ardından ana kayayı oluşturan Trakya formasyonunu veren kum-çakıl tabakası başlamakta ve sonrasında çok katı kıvamdaki yeşil kil başlamaktadır. Caminin temeli ise, döşeme kotuna göre 6-7 m derinliğe oturmaktadır. Depreme karşı güçlendirme çalışmalarında temeli daha sağlam kılmayı ön gören kuyu temel ile caminin dört yönü, betonarme bir perde içine alınmıştır [6]. 

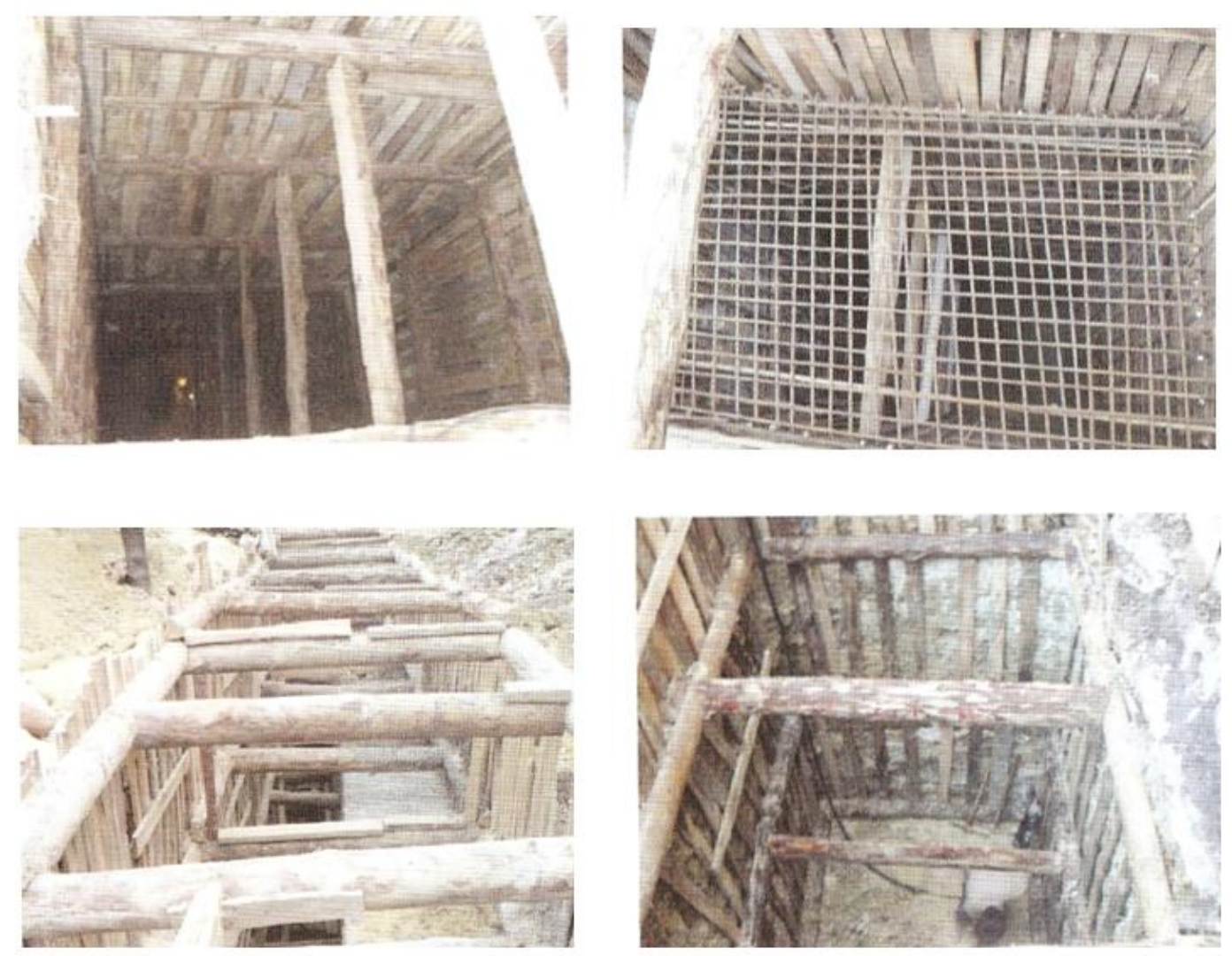

Şekil 26. Edirnekap1 Mihrimah Sultan Camii kuyu temel uygulamas1 [8]

2.2.2. Zemin iyileştirmesine dayanan yöntemler: Yer altı suyunun seviyesindeki değişiklikler, sıkışabilir tabakaların varlığı ve bunların farklı kalınlık veya özellikte olması, zemindeki mukavemet kaybı gibi olumsuzlukların giderilmesi için temel zemininin sslah edilmesi gerekir.

Temel zeminin ıslahında jet-grout ve enjeksiyon uygulaması yapılmaktadır. Uygulanacak yöntemin seçiminde zemin ve yer altı suyunun durumuna ek olarak ulaşılabilme, uygun çalışma alanı, uygulama süresi ve temel takviyesi yapılacak yapının durumu gibi etkenlere dikkat edilmelidir [18].

a) Enjeksiyon yapılması: Temel zemininin veya ana kayanın kayma mukavemetini arttırmak ve geçirgenliğini azaltmak amacıyla kaya veya zemin içerisine basınç altında çeşitli bileşimdeki karışımların basılmasına "enjeksiyon" denir [13]. Zemine ve kayaya enjeksiyon yapılarak boşluklar tamamen veya kısmen doldurulur.

Enjeksiyon yöntemi, önceleri su sızıntılarını önlemek için maden endüstrisinde ve baraj temellerinde sızdırmazlık perdesi oluşturulmasında uygulanmaya başlanmış, daha sonraları ise inşaat mühendisliğinde tünel kazımı esnasında gevşek zeminlerin ve parçalı kayaların stabilizasyonunda, sondaj ve numune alma esnasında su problemlerinin çözümünde, zemin içerisindeki boşlukların doldurularak aşırı oturmaların engellenmesinde, binaların zemin emniyet gerilmelerinin arttrilmasinda ve deprem esnasinda sıvılaşabilecek gevşek, suya doygun granüler zeminlerin sıvılaşma potansiyellerinin azaltılmasında kullanılmıştır [19].

Enjeksiyon uygulama teknikleri enjeksiyon malzemesinin zemin içerisine yerleştirilmesi biçimine bağlı olarak gruplara ayrılır. Buna göre enjeksiyon teknikleri Şekil 27'de gösterilmiştir. 


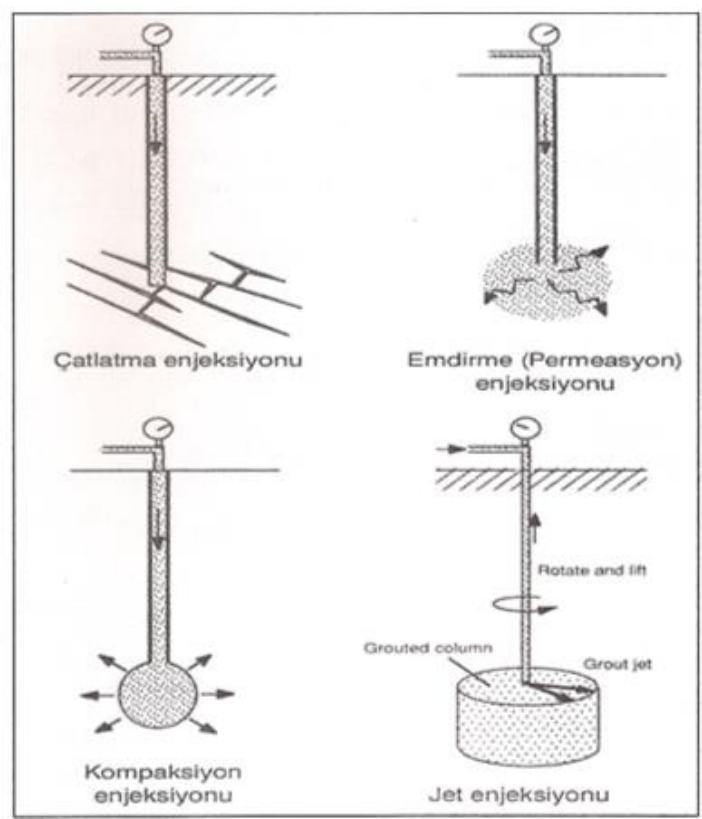

Şekil 27. Enjeksiyon sistemleri şematik gösterimi [19]

Diyarbakır Melik Ahmet Camiinde yaklaşık $1 \mathrm{~m}$ kalınlığındaki beden duvarları belirli noktalarda yumuşak zemin üzerine oturmaktadır. Duvar temel alt kotu ile bazalt yüzey arasında 4 m'yi bulan kot farkları bulunmaktadır. Arada ise killi, bloklu tuğla parçaları içeren değişken kalınlıkta tabakalar mevcuttur. Bu tabakalardaki ince malzemelerin su hareketleri ile yıkanması sonucunda oturmalar oluşmuştur. Çatlakların, yapımı 400 yılı aşan yapıda artmaya devam etmesi, temel zemini erozyonunun sürdüğüne işaret etmektedir. $\mathrm{Bu}$ nedenle eksilen malzemenin hızla doldurulması gerekmektedir. Kullanılacak uygun yöntem ve teknoloji ile oturan temellerin, oturma yönünün tersine, yukarı doğru hareketi sağlanarak, başka ek bir deformasyon gereği olmadan yük taşıyabilmelerinin garanti edilmesi gerekir. Bunun dışında seçilen yöntemin tarihi dokuya zarar vermeden, hızlı ve kolay uygulanabilir olması gerekir. Bütün bu hususlar göz önünde bulundurularak, yapı temel zeminlerinin yüksek genleşmeli kimyasal enjeksiyon yöntemi ile güçlendirilmesi uygun görülmüştür. Bu yöntem ile tüm iç ve dış duvarların tabanındaki zeminler hem boşlukları doldurma hem de kompaksiyon yoluyla sağlamlaştırılmış olmaktadır [20].
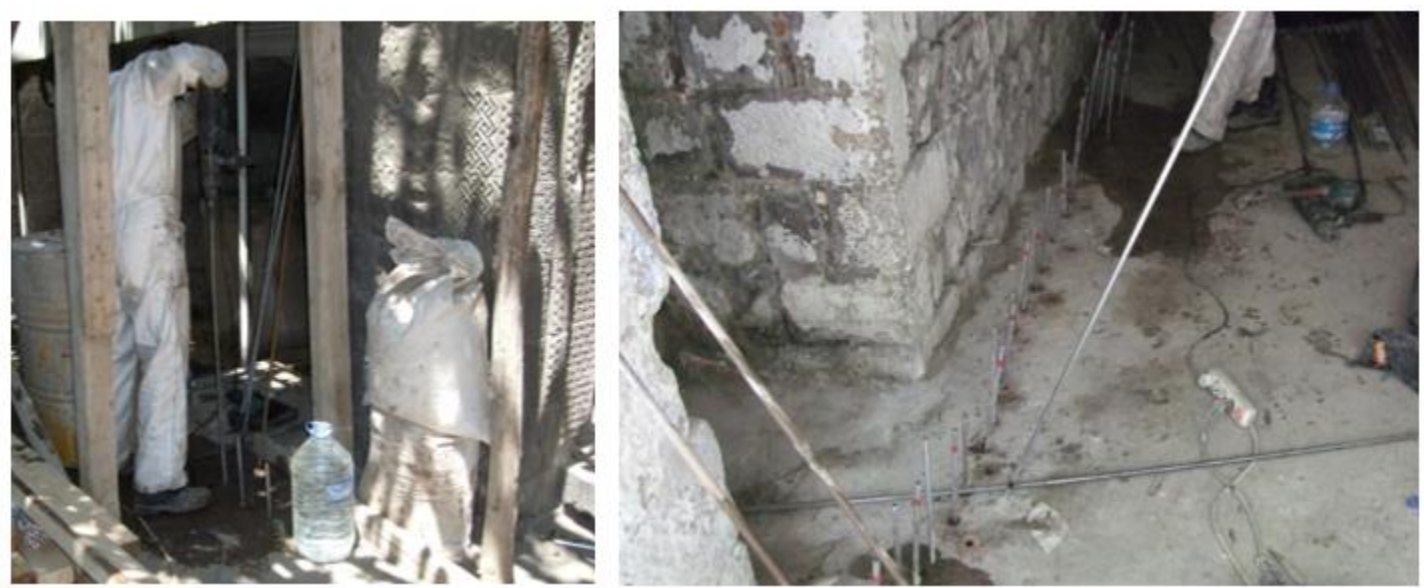

Şekil 28. Diyarbakır Melik Ahmet Camii kimyasal enjeksiyon işlemi, 2008 [21] 


\section{b) Jet grouting:}

Zemin iyileştirmesi, zeminin taşıma gücünü ve elastisite modülünü artırırken aynı zamanda geçirgenliğini azaltarak zeminin mekanik özelliklerini değiştirir ve geliştirir. Bu sonuçlara ulaşmak için en başarılı yöntemlerden birisi jet-grouting yöntemidir [22].

Jet grouting, küçük çaplı nozul ile çok yüksek basınçla zemine enjekte edilen stabilite malzemenin (genellikle çimento-su karışımı) doğal zemin ile karıştırılmasıdır. Stabilite malzeme küçük çaplı nozul ile çok yüksek basınçlarda püskürtülür [18].

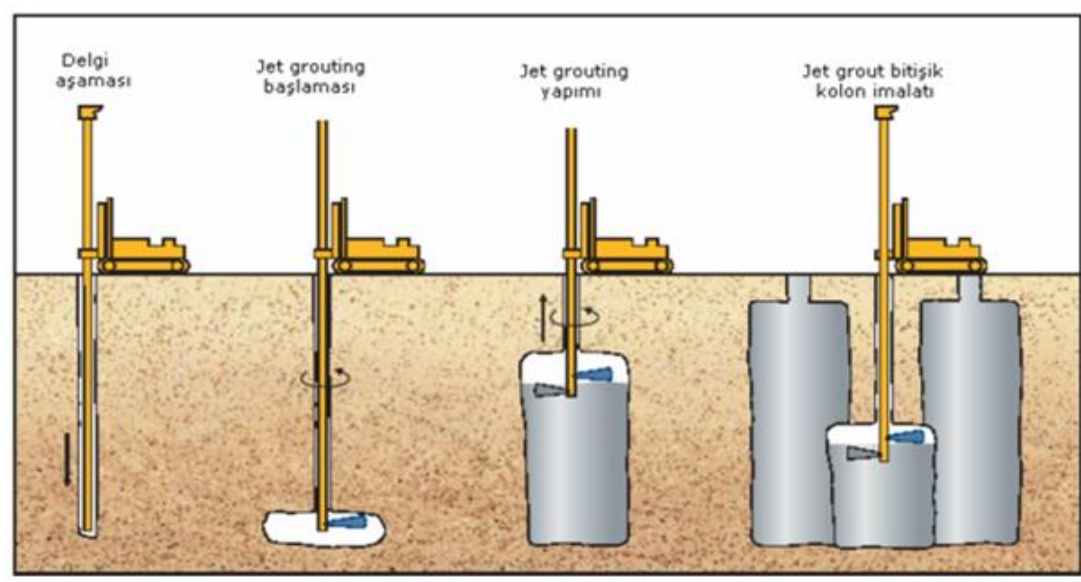

Şekil 29. Jet grouting süreci [18]

2.2.3. Temel yüklerinin daha derindeki taşıyıcı tabakalara aktarılması: Eğer temelin oturmalara karşı takviyesi gerekiyorsa temel yüklerinin oturmalardan etkilenmeyecek kadar sağlam derinlikteki bir zemine aktarılması gerekir [23]. Kazıklı sistemler, yapı yüklerinin daha derin katmanlara aktarılması gerektiği durumlarda uygundur.

Alttan destekleme ve takviye kazıkları olarak da isimlendirilen bu yöntemlere bütün kazık ve benzeri elemanlar toplanabilir [23].

a) Mini kazıklar: Mini kazılar küçük çaplı kazıklar olup kazık gereksinimi olan ve tasarım yükleri 3 tondan 500 tona kadar her türlü zeminde kullanılabilir [18].

Mini kazıklar yük taşıma kapasitesini arttırarak ve oturmaları azaltarak ve mevcut yapıları güçlendirerek birçok zemin iyileştirme uygulamalarında etkili olmaktadır.

Mini kazıklar hem oturma hem de zemin kabarması nedeniyle hasar görmüş yapılarda hem temel takviyesi hem de oturmaların durdurulması amacıyla kullanılmaktadır. Şekil 30' da mini kazıkların yapım aşamaları görülmektedir.

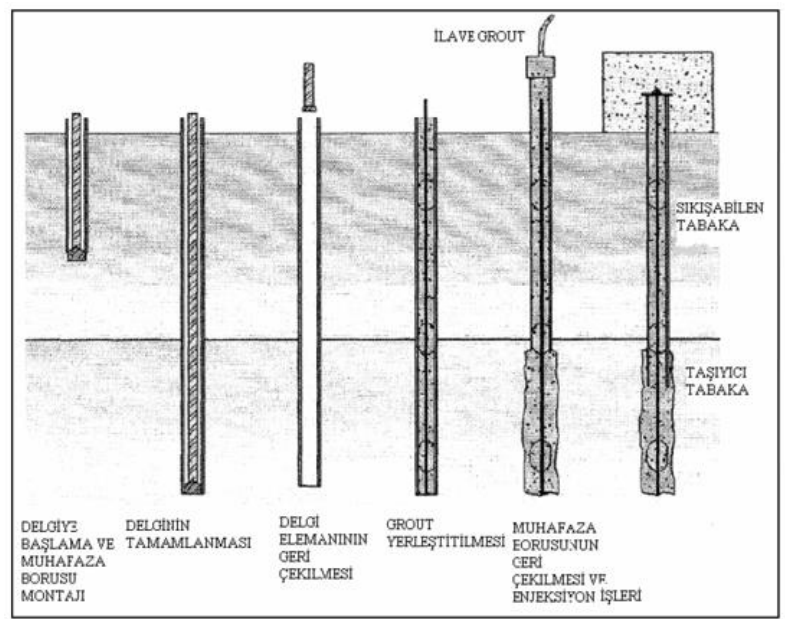

Şekil 30. Mini kazık yapım aşamaları [18]

95 | $\mathrm{P}$ a g e 
Kırıkkale İli, Sulakyurt İlçesi Yeşilyazı Köyü Camiinde oluşan çatlakların nedenlerinin araştırılması amacıyla yapılan sondaj çalışmalarında; çatlakların heyelan hareketine bağlı olarak oluşmuş oldukları gözlemlenmiştir. Bunun neticesinde "Ø80 cm Fore Kazıklı Perde” heyelan önleme sistemi projelendirilmiştir.
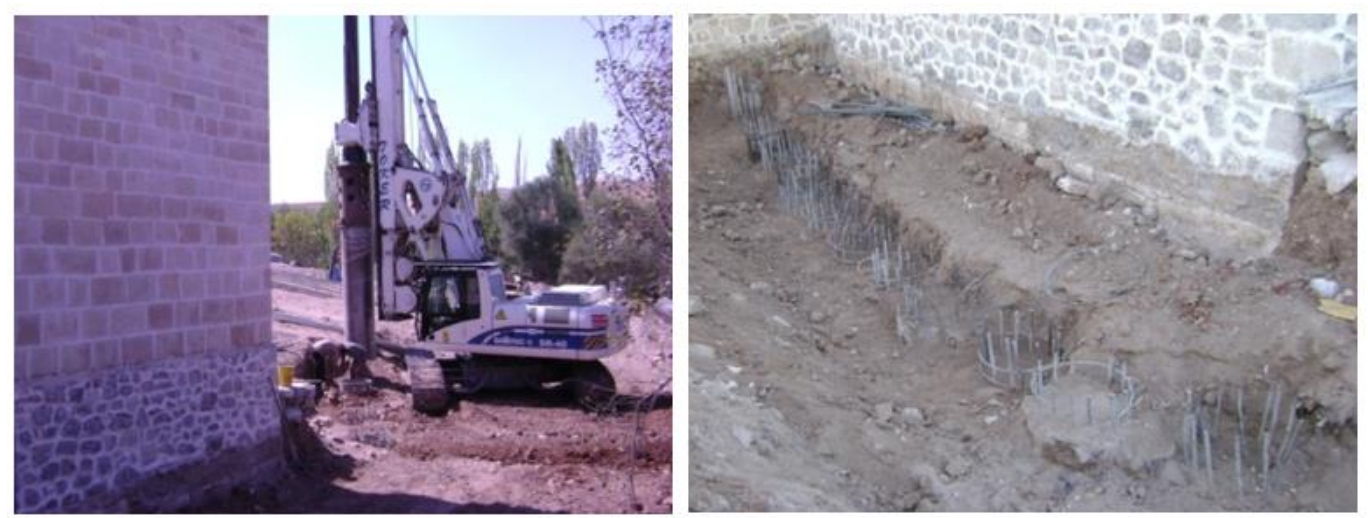

Şekil 31. Kırıkkale Yeşilyazı Camii fore kazık uygulamaları, 2007 [4]

b) İtme Kazıklar: İlke olarak kısa parçalar halinde bir kriko vasıtasıyla, 20-60 cm. ve 0.50-1.50m parçalar halinde zemine itilerek sokulur. Kuvvet doğrudan itme (burgulu) kazığın ucunda olduğu için zemine doğrudan inebilmektedir. Zeminde boşluk oranını azaltır. İtme kazık zemine soktuktan sonra ucu mevcut taşıma kapasitesinin belirlenebilmesi bu yöntemi diğer yöntemlere göre daha güvenilir kılmaktadır [24].

\section{Sonuç}

Restorasyon felsefesinin altında yatan en önemli ölçüt önceki duruma dönebilme özelliğidir, diğer anlatımla yapılan müdahalenin yapıya zarar vermeden kaldırılabilmesi veya bir yenisiyle değiştirilebilmesidir. Geri dönüşümünün anıta zarar vermeden mümkün olmadığı malzeme ve tekniklerin onarımlarda kullanılmasından kaçınılması gerekir. Enjeksiyon uygulamaları, derzleme, dikiş, kesit genişletme, sabitleme, temel sağlamlaştırılması uygulamaları geri dönüşümsüz veya geri dönüşümü çok zor olan uygulamalardır.

Özellikle temelin sağlamlaştırılmasının gerekli olması durumunda hangi yöntemin uygulanacağına karar vermeden önce; deneme çukurları açılmalı, araştırma sondajları ve alınan numuneler üzerinde gerekli olan deneyler yapılmalıdır. Bu uygulamalardan geleneksel yöntemde zeminde oluşturulacak beton kütlesinin yapıda kabul edilemeyecek oturmalara neden olabileceği unutulmamalıdır. Jet grout yönteminin genellikle her türlü zemine uygulanabilmesi, büyük rijitlik sağlaması, yük taşıma elemanının taşıma gücünü artırması, su geçirimsizliği sağlaması gibi avantajlarının yanında yüksek çimento tüketilmesi ve uygulamanın kontrolündeki zorlukları unutulmamalıdır. Mini kazıklar ise özellikle tarihi yapıların temel takviyesinin yapılabilmesi için geliştirilmiş bir teknik olup daha az miktarda çimento kullanımı, daha kolay takip edilmesi gibi avantajları vardır.

Geleneksel yöntemler, enjeksiyon ve jet grout ve kazık uygulamalarında çimento harçlı imalatların yapılması kaçınılmazdır. Bu tür durumlarda çimentoyu ana yapıdan ayıracak horasan sıva, membran uygulamaları vb. önlemlerin mutlaka alınması gerekmektedir.

$\mathrm{Bu}$ çalışma kapsamında anlatılan yöntemlerden destekleme-payandalama, bağlantı çubukları-gergi uygulaması, çemberleme-sıkıştırma, çelik levhalarla kuşaklama yöntemleri görünüşte bir değişiklik yaratmaları nedeniyle çağdaş uygulamalarda pek fazla tercih edilmemektedir.

Yeni geliştirilen malzemelerin, uzun vadedeki davranışları bilinmeden hemen uygulamaya girmesi sıkıntı yaratabilmektedir. Son zamanlarda yapılan uygulamalarda sık sık epoksi enjeksiyonları ve FRP kullanımları gündeme gelmekte ve pek çok uygulamada karşımıza çıkmaktadır. Bu malzemeler ile yapılan uygulamalar şu ân için başarılı görünse de önümüzdeki yıllarda ne tür sonuçlar yaratacağı bilinmemektedir. $\mathrm{Bu}$ nedenle bu malzemelerin kullanımına karar vermeden önce konunun ve malzemelerin çok iyi irdelenmesi ve öyle karar verilmesi gerekmektedir. Eğer uygun şekilde kullanılırlarsa, modern teknikler ortak mirasımızı etkili şekilde korumamıza yardımcı olacak çözümler sunar. Bu yöntemlerden bir kısmı sismik yalıtım ve su yalıtımı gibi diğer yöntemlerin aksine düzeltici önlemler olarak değil sorun önleyici önlemler olarak uygulanmaktadır. 
Restorasyon uygulamalarında başarılı olunabilmesi için disiplinlerarası çalı̧̧malara önem verilmesi gerektiği de unutulmamalıdır. Koruma alanında arkeolog, sanat tarihçisi, mimar, restorasyon uzmanı, mühendis, malzeme bilimcisi, kimyager vb. uzmanların ortak çalışmaları gerekmektedir.

Restorasyon çalışmalarında en uygun olanı seçmek ayrıntılı çalışma isteyen, özen gerektiren bir iştir. Restorasyon ve güçlendirme sırasında çalışanların kültür varlığı değerlerine saygıllı, tarihi eser koruma bilincine sahip, uygun eğitim almış ve tecrübeli elemanlardan oluşması gerekmektedir.

Tarihi bir yapıya müdahale etmeden önce, her yapının kendi içinde değerlendirilmesi gerektiği, her birinin mimari, strüktürel ve malzeme özelliklerinin birbirinden farklı olduğu unutulmamalıdır. Yanlış yapılacak bir müdahalenin yapıyı korumak yerine daha fazla zarar getireceği göz önünde bulundurulmalıdır.

Restorasyon alanında çalı̧̧an ve yapıya yapılacak müdahaleleri tespit edecek kişilerin bu çalışma kapsamında ortaya konan sistemi takip etmeleri durumunda daha sağlıklı sonuçlar ortaya çıkacağ 1 ve tarihi eserlere yapılan müdahalelerin daha doğru olacağına inançla bu çalışma yapılmıştır.

$\mathrm{Bu}$ çalı̧̧ma kapsamında ayrıntılarıyla anlatılan uygulamaların yapıldığı yapıların belli zaman periyotlarında incelemeleri devam ettirilmeli ve yapılan uygulamaların bu yapılara ne tür etkileri olduğu, doğru çözümlerin uygulanıp uygulanmadığının tespiti yapılmalıdır. Ayrıca bu tespitlerin bu alanda çalışan uzmanlarla paylaşılması sağlanmalıdır. Böylece yeni güçlendirme yöntemlerinin daha doğru bir şekilde geliştirilmeleri sağlanabilir.

$\mathrm{Bu}$ çalışma kapsamında geleneksel yığma onarım ve güçlendirme yöntemleri yazar tarafindan incelenmiş̧ir. Bu çalışmadan sonra yapılacak yeni çalışmalarda geleneksel yığma yapılarda taşıyıcı sistem elemanlarının ve özelliklerinin incelenmesi ile bu sistemlerin etkililiğinin araştırılmasında kullanılan bilgisayar programları üzerinde durulmasının uygun ve yararlı olacağı kanaatini taşımaktayız.

\section{Kaynaklar}

[1] Keypour, H., Fahjan, Y., Bayraktar, A., (2007). "Analysis and strengthening methods for historical masonry structures", 5th International Conference on Seismology and Earhquake Engineering, Tahran.

[2] Croci, G., (1998)."The Conservation and Structural Restoration of Architectural H eritage", Computational Mechanics Inc., UK and Boston, USA.

[3] Küçükdoğan, B., (2009). "A Study on Strengthening and Repair Methods for Historical Costructions", Tarihi Eserlerin Güçlendirilmesi ve Geleceğe Güvenle Devredilmesi Sетровуити-2, s. 711-723. Diyarbakır.

[4] Ankara Vakıflar Bölge Müdürlüğü, Arşiv, (2007-2010).

[5] Küçükdoğan, B., (2007). “An Investigation of Strengthening of Historical Masonry Constructions by Steel Skeleton ”, Yüksek Lisans Tezi, Orta Doğu Teknik Üniversitesi Fen Bilimleri Enstitüsü, Ankara.

[6] Mahrabel, H.A., (2006). "Tarihi Yapılarda Taşıyıcı Sistem Özellikleri, Hasarlar, Onarım ve Güçlendirme Teknikleri”, Yüksek Lisans Tezi, İstanbul Teknik Üniversitesi Fen Bilimleri Enstitüsü, İstanbul.

[7] Çıl1, F., Üstündağ, C., Sesigür, H., (2009). "Edirnekapı Mihrimah Sultan Camii Taşıyıcı Sistemde Önerilen Güçlendirme Yönteminin Etkinliğinin İncelenmesi Hakkında Teknik Rapor”, İTÜ Mimarlık Fakültesi Yapı Statiği ve Betonarme Birimi, İstanbul Vakıflar Bölge Müdürlü̈̆̈̈.

[8] İstanbul Vakıflar Bölge Müdürlüğü, Arşiv, (2008-2010).

[9] Bayülke, N., (1992). "Yığma Yapılar”, 2. baskı, T.C. Bayındırlık ve İskan Bakanlığ Afet İ̧sleri Genel Müdürlüğü Deprem Araştırma Dairesi Başkanlığı, Ankara.

[10] Ahunbay, Z., (2004). "Tarihi Çevre Koruma ve Restorasyon", Yapı-Endüstri Merkezi Yapı Yayın, İstanbul.

97 I P a g e

www.iiste.org 
[11] Karakuş, F., Özel Arşivi, Ankara, (2011)

[12] Internet: Wikimedia Commons "Basilica San Vital di Ravenna", http://commons.wikimedia.org/wiki/File:Basilica_San_Vital_di_Ravenna.JPG

[13] Arslan, F., (2006). “Depremden Zarar Görmüş Tarihi Yapıların Güçlendirilmesi”, Yüksek Lisans Tezi, Gazi Üniversitesi Fen Bilimleri Enstitüsü, Ankara.

[14] Sav, M., Kuşüzümü, K. H., (2010). "Restorasyon Çalışmaları Çerçevesinde Mihrimah Sultan Camii”, Vakıf Restorasyon Yillı̆̆, 1: 43-53.

[15] Özdemir, A. A., Özel Arşivi, Ankara, (2011).

[16] Türkiye İşbirliği ve Kalkınma İdaresi Başkanlığı, Arşiv, (2007-2008).

[17] İnternet: Şehirler "Sivas Divriği Ulu Camii”, http://www.sehirler.net/resim-sivas-resimleri-49sivas-divrigi-ulu-camii-878.htm.

[18] Baş, K., (2006). “Temel Takviye Yöntemleri ve Uygulamadan Örnekler”, Yüksek Lisans Tezi, İstanbul Teknik Üniversitesi Fen Bilimleri Enstitüsü, İstanbul.

[19] Tunçdemir, F., (2004). “Temel Zeminlerinin Enjeksiyon Tekniğiyle İyileştirilmesi”, Türkiye Mühendislik Haberleri, 430-2004/2: 59-64.

[20] Yersu Müh. Sondaj İnş. Taah. Tic. Ltd. Şti., (2007). "Diyarbakır Melik Ahmet Camii Zemin ve Temel Etüd Raporu”, Yersu Müh. Sondaj İşs. Taah. Tic. Ltd. Şti., Diyarbakır Vakıflar Bölge Müdürlüğü Arşivi, 7-11,24.

[21] Diyarbakır Vakıflar Bölge Müdürlüğü, Arşiv, (2008).

[22]İnternet: Layne Geoconstruction “Jet Grouting Technical Summary”, http://www.laynegeo.com, (2010)

[23] Ergun, U., (1994). “Temel Takviyesi ve Eski Eserlerin Korunması”, Zemin Mekaniği ve Temel Mühendisliği III. Ulusal Kongresi, ODTÜ, Ankara, 887-917.

[24] Naml, M., (2001). “Tarihi Yapıların Temel Sistemleri ve Temel Takviyesi Yöntemleri”, Yüksek Lisans Tezi, İstanbul Teknik Üniversitesi Fen Bilimleri Enstitüsü, İstanbul. 